\title{
Chronicling the discovery of interferon tau
}

\author{
Fuller W Bazer ${ }^{1}$ and William W Thatcher ${ }^{2}$ \\ ${ }^{1}$ Department of Animal Science, Texas A\&M University, College Station, Texas, USA and ${ }^{2}$ Department of Animal \\ Science, University of Florida, Gainesville, Florida, USA
}

Correspondence should be addressed to FW Bazer; Email: fbazer@cvm.tamu.edu

\begin{abstract}
It has been 38 years since a protein, now known as interferon tau (IFNT), was discovered in ovine conceptus-conditioned culture medium. After 1979, purification and testing of native IFNT revealed its unique antiluteolyic activity to prevent the regression of corpora lutea on ovaries of nonpregnant ewes. Antiviral, antiproliferative and immunomodulatory properties of native and recombinant IFNT were demonstrated later. In addition, progesterone and IFNT were found to act cooperatively to silence expression of classical interferon stimulated genes in a cell-specific manner in ovine uterine luminal and superficial glandular epithelia. But, IFNT signaling through a STAT1/STAT2-independent pathway stimulates expression of genes, such as those for transport of glucose and amino acids, which are required for growth and development of the conceptus. Further, undefined mechanisms of action of IFNT are key to a servomechanism that allows ovine placental lactogen and placental growth hormone to affect the development of uterine glands and their expression of genes throughout gestation. IFNT also acts systemically to induce the expression of interferon stimulated genes that influence secretion of progesterone by the corpus luteum. Finally, IFNT has great potential as a therapeutic agent due to its low cytotoxicity, anti-inflammatory properties and effects to mitigate diabetes, obesity-associated syndromes and various autoimmune diseases.

Reproduction (2017) 154 F11-F20
\end{abstract}

\section{Embryonic death, uterine factors and pregnancy}

A number of historical events set the stage for research leading to the discovery of pregnancy recognition signals in pigs and ruminant species. Bazer and coworkers (1969) noted that hormone-induced superovulation and feeding high-energy feeds, to increase the number of ovulations in polytocous animals, led to greater rates of embryonic death due to inherent limitations within individual embryos and to maternal limitations that restrict litter size or both. Embryonic death losses occur during the peri-implantation period of pregnancy (Boyd 1965) and increase following hormonal superovulation (Fowler \& Edwards 1957, Adams 1960, Hafez 1964) or the transfer of additional embryos to uterine horns of mice (McLaren \& Michie 1959, Adams 1960, Hafez 1964). Bazer et al. (1969) postulated that a biochemical factor in the uterine lumen limited the number of blastocysts that undergo implantation and placentation. This idea supported results of Krishnan and Daniel (1967) who discovered blastokinin (also known as uteroglobin). Blastokinin was reported to induce the development of morulae to blastocysts in rabbits. The fact that most embryonic deaths in pigs occur during the peri-implantation period of pregnancy (Gossett \& Sorensen 1959) suggested that the major causes were failure of blastocysts to develop and/or uterine capacity, both of which limited litter size at term (Bazer et al. 1968, 1969).

\section{Concept of pregnancy recognition signaling}

While attention was being given to embryonic death, uterine factors and pregnancy in pigs, Short (1979) clarified the terms luteotrophic, luteolytic, antiluteolytic and pregnancy recognition signaling. Prostaglandin $F_{2 \alpha}$ (PGF) was identified as the uterine-derived luteolytic hormone responsible for regression of the $\mathrm{CL}$ and cessation of secretion of progesterone by luteal cells in nonpregnant subprimate mammals (Schramm et al. 1983). The antiluteolytic signals from pig and ruminant conceptuses had not been identified in 1969, but it was assumed that those signals inhibited luteolytic actions of PGF or abrogated the mechanism(s) for PGFinduced luteolysis. Pregnancy recognition signals were diverse (Flint et al. 1979). For example, available results indicated the lack of need for pregnancy recognition signals for dogs, ferrets and marsupials, but systemic effects of estrogens on functions of corpora lutea $(\mathrm{CL})$ in pregnant pigs had been reported (Kraeling et al. 1975). Short (1979) reported that abnormal conceptuses failed to signal pregnancy recognition. Thus, the stage was set for research to identify pregnancy recognition signals in mammals. This challenge was addressed in our

This paper is part of an Anniversary Issue celebrating 30 Years of Interferon-Tau. The Guest Editor for this section was Professor R Michael Roberts. 
laboratories at the University of Florida through research with pigs, sheep and cows.

\section{Pregnancy recognition signaling in pigs}

Research on proteins in uterine secretions, their endocrine regulation and their influence on embryonic survival in pigs (see Bazer 1975) led to research on mechanisms for establishment and maintenance of pregnancy in pigs, sheep and cows. Studies of the oestrous cycle and pregnancy in pigs revealed that PGF was released into the uterine venous system in a pulsatile manner during the period of luteolysis in cyclic, but not pregnant gilts (see Bazer \& Thatcher 1977). Furthermore, it was discovered that the CL of pigs were not responsive to luteolytic effects of PGF until about Day 14 of the oestrous cycle; therefore, PGF was ineffective as a hormone to synchronize estrus in pigs (see Bazer et al. 1982).

Our research on early pregnancy in pigs revealed that blastocysts hatch from the zona pellucida between Days 6 and 7, expand to large spherical blastocysts by Day 10, and transition to tubular and filamentous forms by Day 12 ( $1 \mathrm{~mm}$ diameter $\times 200 \mathrm{~mm}$ length) and Day 15 (800-1000 mm in length) of gestation (Geisert et al. $1982 a, b, c)$. It was later established that elongating pig conceptuses secrete oestrogens (Perry et al. 1973, Fischer et al. 1985), which are the pregnancy recognition signal in pigs (Bazer \& Thatcher 1977). The endocrineexocrine theory for pregnancy recognition in pigs was reported by Bazer and Thatcher (1977). The theory of pregnancy recognition signaling in pigs was based on results indicating that oestrogens, acting alone or in concert with prolactin, change the direction of secretion of PGF from uterine epithelia from an endocrine to an exocrine direction. PGF is released from uterine epithelia into the vasculature of the uterus (endocrine secretion) in a pulsatile manner between Days 15 and 16 of the oestrous cycle to induce luteal regression. However, PGF is secreted by uterine epithelia into the uterine lumen (exocrine direction) of pregnant pigs where it is sequestered and metabolized (see Bazer \& Thatcher 1977). This theory was confirmed and modified (see Zeicik et al. 2011).

\section{Pregnancy recognition signaling in ewes}

Rowson and Moor (1967) provided the first evidence that ovine conceptuses secrete a substance(s) that extends CL life-span in ewes and that the conceptus must be present in the uterine horn ipsilateral to the ovary bearing the $\mathrm{CL}$ in order to prevent the regression of the CL. Those results indicated that the conceptus factor acted locally to prevent $\mathrm{CL}$ regression. The 'antiluteolytic factor' was thermolabile, degraded by proteases and produced by ovine conceptuses between Days 12 and 21 of pregnancy
(Moor \& Rowson 1966a,b, Rowson \& Moor 1967, Moor 1968). They also found that a blastocyst must be transferred into the uterine horn ipsilateral to the ovary bearing a CL by Day 12 or Day 13 of the oestrous cycle for establishment of a successful pregnancy. This was confirmed by a study in which they found that length of the oestrous cycle of ewes was only affected when conceptuses were flushed from the uterus on or after Day 13 of pregnancy (Moor \& Rowson 1966a, Moor et al. 1969). Martal (1979) and Ellinwood and coworkers (1979) reported an antiluteolytic factor in homogenates of sheep conceptuses collected on Days 14-15, but not Days 21-25 of pregnancy and homogenates of Day 14 and Day 15 conceptuses extended CL lifespan and inter-oestrous intervals when infused into the uterine lumen of cyclic ewes (Rowson \& Moor 1967, Ellinwood et al. 1979, Martal et al. 1979). The antiluteolytic factor in the conceptus homogenates was confirmed to be inactivated by heat and proteases. Martal et al. (1979) named the antiluteolytic factor trophoblastin. Thus, it was established that maternal recognition of pregnancy signaling in ewes involved a protein secreted by the conceptus between Days 12 and 21 after onset of estrus and mating.

\section{Discovery of interferon tau as the pregnancy recognition signal in ruminants}

Our research on the estrogen-dependent endocrineexocrine theory of pregnancy recognition in pigs (Bazer \& Thatcher 1977) biased our thinking toward the concept of oestrogen being the pregnancy recognition signal in other livestock species, e.g., sheep and cows. Therefore, we studied steroid metabolism by uterine endometria and conceptuses from sheep and cows. Results of those studies provided no evidence for conceptus-derived oestrogens being the antiluteolytic factor secreted by conceptuses from sheep or cow conceptuses during the period of pregnancy recognition signaling (see Eley et al. 1979). Therefore, we cultured sheep conceptuses in medium containing radiolabeled amino acids and analyzed culture medium to detect radiolabeled proteins that were synthesized de novo. We were using this method to identify proteins synthesized de novo and secreted into culture medium by explants of pig endometria (see Basha et al. 1980) (see Fig. 1).

Ovine conceptus conditioned culture medium was first subjected to Sephadex G200 gel filtration chromatography, and we discovered a low-molecularweight radiolabeled protein that is now known as ovine interferon tau (IFNT) (Wilson et al. 1979). Later, bovine IFNT was identified using the same methods (Lewis et al. 1979). This research was supported by a United States Department of Agriculture, Cooperative States Research Service Grant No. 61615162 titled 'Increasing Embryo Survival In Cattle' awarded to Drs Thatcher and Bazer. 


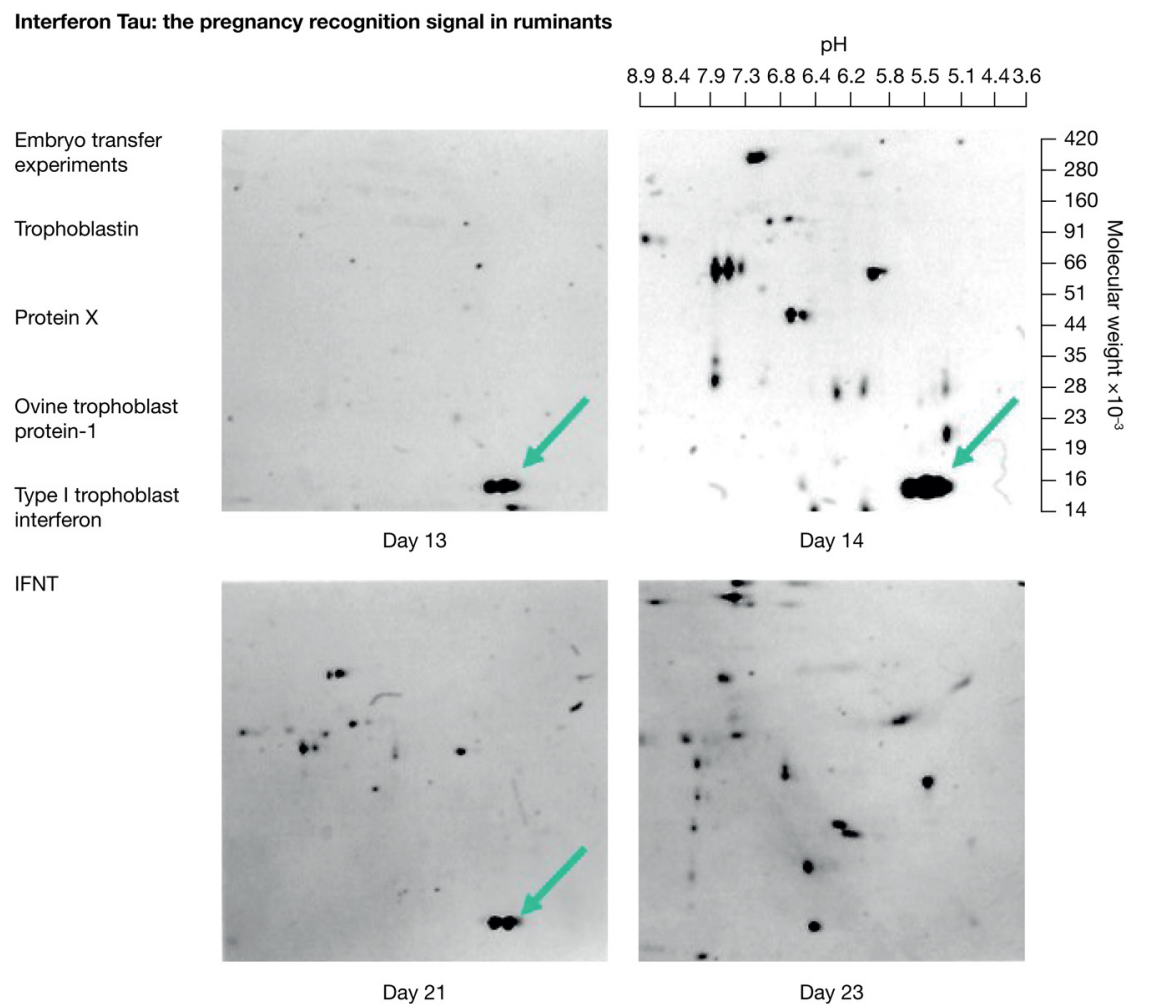

Figure 1 This figure illustrates the sequence of events that led to the discovery of interferon tau (IFNT) in ovine conceptus conditioned culture medium and identified in this figure of a two-dimensional polyacrylamide gel by green arrows. Details of how embryo transfer experiments contributed to discovery of pregnancy recognition signaling are provided in the text. Protein X, trophoblastin, ovine trophoblast protein 1 and type 1 trophoblast interferon were names given to the protein, which was finally named interferon tau.
The discovery of ovine IFNT was by Dr Bazer's graduate student, Michael Wilson. After that, studies were led by Dr Gregory Lewis, a postdoctoral fellow working with Drs Thatcher and Bazer, and Dr James Godkin, a postdoctoral fellow working with Drs R Michael Roberts and Bazer. Wilson switched majors to Agricultural Economics and Dr Lewis focused his research on prostaglandins secreted by the uterus and conceptus. Thus, much of the early research on the protein originally called 'Protein $X$ ' and later ovine trophoblast protein one (oTP1) was led by $\mathrm{Dr}$ James Godkin. As noted previously, Martal et al. (1979) purified the same protein as protein X/oTP1 and called it 'trophoblastin.'

In order to identify when during early pregnancy the antiluteolytic protein(s) was secreted, sheep conceptuses from Days 10-25 of pregnancy were cultured in the presence of radioactive amino acids. This allowed detection of de novo synthesized and secreted proteins in culture medium using two-dimensional polyacrylamide gel electrophoresis and fluorography (Godkin et al. 1982). One of the radiolabeled proteins in culture medium had a molecular weight of $17-20 \mathrm{kDa}$, which was similar to the estimated size of the protein(s) originally identified using gel filtration chromatography. Because the 17-20 kDa protein was the first major protein secreted by the ovine conceptus, it was initially designated protein $X$, which was renamed ovine trophoblast protein one (oTP-1) (Godkin et al. 1984). oTP-1 was not synthesized and secreted by ovine conceptuses beyond Day 21 of pregnancy, which agreed with findings of Moor and Rowson (1966a) and Moor and Rowson (1966b). Intrauterine injections of semi-purified oTP-1 between Days 12 and 14 of the oestrous cycle extended inter-estrous intervals and maintenance of $\mathrm{CL}$ that continued to produce progesterone (Godkin et al. 1984). Those results strongly suggested that oTP-1 was the antiluteolytic factor secreted by ovine conceptuses. However, Vallet and coworkers (1988) provided clear evidence that highly purified OTP-1 alone, in the total array of proteins secreted by ovine conceptuses, abrogated the luteolytic mechanism.

Immunocytochemical and in situ hybridization analyses revealed that oTP1 was expressed by mononuclear trophectoderm cells (Godkin et al. 1984, Farin et al. 1990, Guillomot et al. 1990) with maximal production between Days 14-16 of pregnancy. Day 15 ovine conceptuses released greater than $100 \mu \mathrm{g}$ of the protein in culture in a 24-h period (Ashworth \& Bazer 1989b), and expression of oTP-1 mRNA by the conceptus is greatest around Day 14 of pregnancy in sheep and Day 20 of pregnancy in cattle (Hansen et al. 1985, Stewart et al. 1987). However, low amounts of IFNT are secreted by ovine conceptuses as early as Days 8 and 10 of pregnancy (Ashworth \& Bazer 1989a). Expression of oTP1 mRNA is detectable on Days 10 and 11, maximum after Day 13 and declines after Day 17 of pregnancy (Farin et al. 1990, Guillomot et al. 1990). The decrease in IFNT gene expression occurred after attachment of conceptus trophectoderm to the uterine luminal epithelium during implantation. Thus, IFNT 
is produced transiently by ovine conceptuses, with expression being greatest prior to the expression of mRNAs for estradiol (ESR1) and oxytocin (OXTR) receptors in uterine epithelia between Days 13 and 14 of the oestrous cycle in ewes.

Parallel studies with bovine and ovine oTP1 confirmed that they are antiluteolytic signals for pregnancy in both species (Knickerbocker et al. 1986, Helmer et al. 1987, 1989, Thatcher et al. 1989, Meyer et al. 1995, Tysseling et al. 1997). Using ovine IFNT, Newton and coworkers (1996) demonstrated that it is antiluteolytic when injected into the uterine lumen of goats.

\section{Cloning the gene for oTP1}

Dr James Lauderdale, a colleague of Drs Thatcher and Bazer, obtained permission for Dr Russell Anthony, a postdoctoral fellow working with Drs Roberts and Bazer, to work in the laboratories of Drs K R Marotti and $\mathrm{H}$ G Polites at the Upjohn Company to clone the gene for OTP1. However, with Dr Roberts move from the University of Florida to the University of Missouri, cloning of the oTP1 gene was continued by Dr Kaz Imakawa, a graduate student in Dr Roberts' laboratory. Imakawa and coworkers (1987) and Stewart and coworkers (1987) cloned the gene for OTP-1, and it was found to be a member of the Type I interferon alpha (IFNA) family of proteins. The identity between the 172 amino acid ovine oTP-1 and the 165 amino acid bovine IFNA 1 mRNA and protein was found to be $63 \%$ and $50 \%$, respectively (Roberts 1991, 1993). However, homology between OTP1 and bovine IFN omega 1 (IFNW1) mRNAs and proteins was $85 \%$ and $72 \%$, respectively. Thus, oTP1 is in a distinct subgroup of the Type I IFN family (Imakawa et al. 1987). Because of its unique developmental expression by trophectoderm and its relatedness to other Type I IFNs (alpha, beta, omega), oTP1 was given the name interferon tau (IFNT) by the International Interferon Society (see Roberts 1991).

\section{Production of recombinant ovine interferon tau and its biological activities}

Using a highly purified native IFNT, we demonstrate its potent antiviral (Pontzer et al. 1988, 1990), antiproliferative (Pontzer et al. 1991) and immunosuppressive (Pontzer et al. 1994, Newton et al. 1996) properties, as well as insight into the structural motif of IFNT (Jarpe et al. 1994). Subsequently, we produced and expressed a synthetic gene for ovine IFNT using the Pichia pastoris yeast system. The recombinant IFNT has immunosuppressive, antiviral, antiproliferative and antiluteolytic properties equivalent to native IFNT (Ott et al. 1991, Van Heeke et al. 1996).

\section{Mechanisms for the antiluteolytic effects of interferon tau}

Our research on mechanisms of action of IFNT as the antiluteolyic pregnancy recognition signal in ruminants was conducted at the University of Florida and at Texas A\&M University. Dr John McCracken's model of the 'progesterone block' for regulation of the oestrous cycle in ewes (see Schramm et al. 1983) provided the basis for our hypotheses on mechanisms whereby IFNT signals pregnancy recognition in sheep and other ruminant species. We tested the hypothesis that progesterone (P4) blocks the expression of receptors for estradiol (ESR1) and oxytocin (OXTR) for a finite period of time, 10-12 days, after which time progesterone (P4) downregulates the expression of its own receptor (PGR) to allow upregulation of expression of ESR 1 and OXTR genes. Then, pulsatile release of oxytocin from the posterior pituitary gland and CL elicit secretion of luteolytic pulses of PGF from uterine epithelia on Days 15 and 16 to cause regression of the $C L$ and return to oestrus by the ewe. The following evidence indicates that IFNT alone is the pregnancy recognition component in ewes and other ruminant species: (1) IFNT directly silences transcription of the ESR1 gene and, indirectly, the E2-induced expression of OXTR in uterine luminal and superficial glandular epithelia to abrogate development of the endometrial luteolytic mechanism involving oxytocin-induced luteolytic pulses of PGF (Spencer et al. 1995a,b, 1998, Fleming et al. 2001, 2006); (2) basal concentrations of PGF and PGE2 in maternal blood are greater in pregnant than cyclic ewes due to continued expression of prostaglandin endoperoxide synthase 2 (PTGS2) (Charpigny et al. 1997b, Simmons et al. 2010); (3) IFNT silences the expression of ESR1, which prevents oestradiol (E2) from upregulating the expression of PGR in endometrial epithelia (Fincher et al. 1986, Vallet et al. 1988, Mirando et al. 1990, Spencer et al. 1995b) and (4) downregulation of expression of PGR in uterine epithelia is required for expression of P4-induced and IFNT-stimulated genes that support the development of the conceptus (Spencer et al. 1998, Choi et al. 2001, Bazer et al. 2014).

Caprine IFNT, secreted between Days 16 and 21 of gestation, is the pregnancy recognition signal that prevents pulsatile release of luteolytic PGF by uterine epithelia and extends CL lifespan in goats (Newton et al. 1996). Bovine IFNT, secreted between Days 12 and 38 of pregnancy, prevents the secretion of luteolytic pulses of PGF by uterine epithelia and blocks effects of exogenous E2 and oxytocin to stimulate pulsatile release of PGF by bovine uterine epithelia. Expression of ESR 1 and OXTR mRNAs are either downregulated or ESR1 and OXTR are less abundant or less responsive to E2 and oxytocin in endometria of pregnant compared to cyclic cows or cows receiving intrauterine injections of either ovine or bovine IFNT (Knickerbocker et al. 1986, 
Helmer et al. 1987, 1989, Thatcher et al. 1989, Meyer et al. 1995, Tysseling et al. 1997).

Interferon tau, the sole factor produced by the conceptus that prevents development of the endometrial luteolytic mechanism in sheep (Vallet et al. 1988), does not stabilize expression of $P G R$ in uterine epithelia during pregnancy (Spencer \& Bazer 1995, 1996, Spencer et al. 1995b). Rather, IFNT acts on uterine luminal and superficial glandular epithelia to inhibit transcription of ESR1 and OXTR genes and abrogate development of the endometrial luteolytic mechanism (Spencer \& Bazer 1996, Spencer et al. 1998, Fleming et al. 2001). The increases in expression of ESR 1 and OXTR mRNAs in uterine luminal and superficial glandular epithelia between Days 11-17 post-oestrus in cyclic sheep do not occur in pregnant ewes (Spencer \& Bazer 1995) or in cyclic ewes in which recombinant ovine IFNT is injected into the uterine lumen (Spencer et al. 1995c). Thus, oxytocin is unable to induce secretion of luteolytic pulses of PGF. However, basal production of PGF is greater in pregnant than cyclic ewes as IFNT does not inhibit the expression of PTGS2 in uterine LE/ sGE (Charpigny et al. 1997b, Simmons et al. 2010). The molecular mechanisms involved in IFNT silencing of expression of ESR1 is likely due to IFNT-inducing expression of IFN regulatory factor two (IRF2), a potent repressor of transcription, in uterine luminal and superficial glandular epithelia (Spencer et al. 1998, Choi et al. 2001, Fleming et al. 2001). In the absence of ESR1, ovine uterine epithelia do not express OXTR (Fleming et al. 2006). The promoter region of the OXTR gene does not contain an estrogen response element, rather ESR1 binds to SP1 elements and interacts with two GC-rich SP1-binding sites, located within 140 bp of the translational start site for OXTR (Fleming et al. 2006). Mutation analyses of the OXTR promoter revealed that the proximal SP1 sites mediated ESR1 action as well as basal activity of the promoter (Fleming et al. 2006).

In contrast to the ovine OXTR gene, the bovine OXTR gene lacks a classical palindromic oestrogen response element (Bathgate et al. 1998), and there is no change in ESR1 expression in uterine epithelia between pregnant and nonpregnant cows (Robinson et al. 1999). Thus, pregnancy and IFNT may alter expression of OXTR mRNA independent of ESR1 in the endometrium of cattle. IRF2 can regulate the expression of the bovine OXTR gene (Telgmann et al. 2003) suggesting its common role as an effector of the antiluteolytic actions of IFNT in bovine endometria for the establishment of pregnancy.

\section{Progesterone-induced and interferon tau-stimulated genes in the ovine uterus}

In ewes, progesterone (P4) induces and IFNT further stimulates the expression of many genes. However, a fundamental unanswered question is whether actions of progestamedins (e.g., fibroblast growth factors 7 and 10, and hepatocyte growth factor) from uterine stromal cells and IFNT act on uterine epithelia or other uterine cell types via novel non-classical cell signaling pathways, independent of PGR and STAT1. Progestamedins and IFNT can signal via mitogen-activated protein kinases (MAPK) and phosphoinositide-3 kinase (PI3K) to affect gene expression and uterine receptivity to implantation (Platanias 2005). All Type I IFNs bind the same receptor, but may activate novel cell-specific signaling pathways. Thus, IFNT may differentially affect gene expression in uterine luminal and superficial glandular epithelia vs uterine glandular epithelium and stromal cells. This cell-specific gene expression in the ovine uterus is due to expression of IRF2 only by uterine luminal and superficial glandular epithelial cells, which is likely responsible for the silencing expression of classical interferon stimulated genes by uterine luminal and superficial glandular epithelia (Spencer et al. 1998, Choi et al. 2001).

In addition to signaling pregnancy recognition in ruminants, IFNT limits expression of classical interferonstimulated genes to ovine uterine glandular epithelium and stromal cells, which do not express IRF2. However, there are many P4-induced and IFNT-stimulated genes expressed by uterine luminal and superficial glandular epithelia that lack both PGR and STAT1 (signal transduction and activator of transcription 1). This is because IFNT induces expression of IRF2 in uterine luminal and superficial glandular epithelia in ewes to silence expression of ISGs, but induces expression of many novel genes that support growth and development of the conceptus. Those genes include: wingless-type MMTV integration site family member 7A (WNT7A), LGALS15 (galectin 15), HIF2A (hypoxia-inducible factor 2A), CTSL (cathepsin L), CST3 (cystatin C), SLC5A1 (solute carrier family 5, sodium/glucose cotransporter, member 1), GRP (gastrin releasing peptide), HSD11B1 (11 beta hydroxysteroid dehydrogenase type 1), IGFBP1 (insulin-like growth factor binding protein 1) and SLC7A2 (solute carrier family 7 , cationic amino acid transporter, y+ system, member 2) (Bazer et al. 2009, 2015a,b). Inhibition of the classical Janus kinase (JAK):STAT cell signaling pathway by IRF2 likely allows expression of the P4-induced and IFNT-stimulated genes to increase in response to both the progestamedins and IFNT via MAPK and PI3K cell signaling in uterine luminal and superficial glandular epithelia. These include genes for transport of glucose (SLC2A1 and SLC5A11) and amino acids (SLC7A1 and SLC7A2) into the uterine lumen to stimulate proliferation of trophectoderm cells by activating the glutamine:fructose- 6 -phosphate amidotransferase (GFAT)-mediated FK506-binding protein 12-rapamycin-associated protein 1 (FRAP1, formerly mTOR) signaling pathway. Arginine also affects fetal-placental growth and development through effects on synthesis of nitric oxide (NO) and polyamines 
that stimulate vascular functions, as well as DNA and protein synthesis for proliferation and differentiation of cells, respectively. However, expression of major histocompatibility complex class I molecules and $\beta 2$ microglobulin genes that regulate immune rejection responses is silenced in ovine uterine luminal and superficial glandular epithelia to protect the conceptus allograft from rejection by the maternal immune system.

\section{Interferon tau and the servomechanism for maintenance of pregnancy}

Interferon tau is a component of the servomechanism for the maintenance of pregnancy in ewes. The servomechanism provides for reciprocal communication between the conceptus and endometrium during implantation and synepitheliochorial placentation in ewes (Spencer et al. 1999, 2007, Stewart et al. 2000, 2001, Noel et al. 2003). This concept is based on evidence that IFNT extends lifespan of CL initially and that placental lactogen (CSH1) and/or placental growth hormone $(\mathrm{GH} 1)$ secreted by the trophectoderm/chorion from Day 15 to term, and Days 35-65 of pregnancy, respectively, reinforce the antiluteolytic effects of IFNT. However, there were no independent or interactive effects of $\mathrm{CSH} 1$ and $\mathrm{GH} 1$ on luteal maintenance and function in ewes. Importantly, both $\mathrm{CSH} 1$ and $\mathrm{GH} 1$ affected the development and function of uterine glands, but only if the uterus was first exposed to intra-uterine IFNT between Days 11 and 21 and then intra-uterine $\mathrm{CSH} 1, \mathrm{GH} 1$ or $\mathrm{CSH} 1$ and $\mathrm{GH} 1$ between Days 16 and 29 after onset of estrus. During gestation, endometrial gland hyperplasia occurs between Days 15 and 50 of pregnancy and hypertrophy of the uterine glands to increase surface area for maximal production of histotroph occurs after Day 60 of gestation. Sequential exposure of the ovine endometrium to E2, P4, IFNT, CSH1 and $\mathrm{GH} 1$ constitutes a 'servomechanism' responsible for activating and maintaining endometrial remodeling, secretory function and uterine growth during gestation. Downregulation of PGR in uterine epithelial cells is a prerequisite for $\mathrm{P} 4$-induced expression of genes in uterine GE that include SPP1 (secreted phosphoprotein 1), UPTI (uterine plasmin trypsin inhibitor) and STC1/ STC2 (stanniocalcin). Treatment of ewes with a combination of P4 and E2 increases the expression of ESR 1 and $P G R$ in uterine GE, and the increase in ESR1 inhibits expression of SPP1 and UPT1. Thus, IFNT is a prerequisite to the developmentally programmed sequence of events, mediated by specific paracrineacting factors at the conceptus-endometrial interface, responsible for both remodeling of the inter-caruncular endometrium and differentiated functions of uterine GE to increase production of histotroph for fetal-placental growth during gestation.

\section{Interferon tau induced effects distal to the conceptus/uterine complex}

In addition to the paracrine effects of IFNT secreted by the trophectoderm on the underlying endometrium, IFNT-stimulated genes (ISGs) are expressed in blood cells and cellular components of the CL. IFNT secreted (Oliveira et al. 2008) or infused into the uterine vein (Bott et al. 2010) of sheep initiated a peripheral antiviral response (e.g., increased expression of interferon stimulated gene 15 (ISG15) in immune cells in maternal blood) to possibly protect the pregnancy from maternal viral infection. The endocrine action of IFNT impacts the $\mathrm{CL}$ to induce luteal resistance to PGF (Antoniazzi et al. 2013), enhances expression of ISG15 in luteal cells (Oliveira et al. 2008, Yang et al. 2010) and/or alters functions of immune cells within the $\mathrm{CL}$ to maintain $\mathrm{CL}$ function and pregnancy (Shirasuna et al. 2015).

A bovine animal model was developed to further understand the integration of signalling between IFNT and immune cells that contribute to maintenance of progesterone secretion by large luteal cells in pregnancy (Shirasuna et al. 2015). Compared to nonpregnant cows, the $\mathrm{CL}$ of pregnant cows on Day 16 after insemination have greater expression of mRNAs for ISG15 and interleukin 8 (IL8), as well as IL8 protein, while expression of $T N F \alpha$ mRNA is reduced in pregnant compared to non-pregnant cows. Furthermore, CL of pregnant cows have greater numbers of neutrophils.

Although IFNT does not directly affect the secretion of progesterone (P4) by large luteal cells or migration of neutrophils, IFNT increased expression of ISG15 and IL8 mRNAs in large luteal cells. Both IL8 and ISG15 stimulate neutrophil migration in vitro, but IFNT was ineffective. If neutrophils were pre-treated with IFNT, then IL8 induced a greater neutrophil migration response. When large luteal cells were co-cultured with neutrophils, secretion of $\mathrm{P} 4$ increased in response to IFNT compared to amounts of P4 secreted when large luteal cells were cultured alone or co-cultured with neutrophils, but not treated with IFNT. IL8-stimulated secretion of P4 by large luteal cells cultured alone. The increase in neutrophils and IL8 within the CL of pregnant cows suggests additional complementary involvement of IFNT within the CL to maintain secretion of P4 and pregnancy in cows. This model indicates that IFNT stimulates expression of IL8 in luteal cells that activates and induces migration of neutrophils, which stimulate large luteal cells to increase or sustain secretion of P4 in cows during early pregnancy. Thus, IFNT appears to induce both antiluteolytic and complementary intraovarian effects that ensure maintenance of a functional $\mathrm{CL}$ for maintenance of pregnancy. Further investigations into the integration of the immune and endocrine systems of early pregnancy, via IFNT acting distal to the conceptus/endometrial unit are warranted to advance 
understanding of mechanisms for maintaining the $\mathrm{CL}$ of early pregnancy.

\section{Potential therapeutic effects of oral interferon tau}

The effects of IFNT are not limited to ruminant species and pregnancy. There are reports that IFNT induces immunological tolerance in several animal models. Matings between $\mathrm{DBA} / 2 \times \mathrm{C} 57 \mathrm{~B}$ mice result in high rates of fetal resorptions, but treatment of dams with exogenous IFNT prevents this pregnancy wastage in an IL10-dependent manner (Chaouat et al. 1995, 2004). In the experimental allergic encephalomyelitis (EAE) mouse model, IFNT suppresses EAEby stimulating IL10, i.e., aTh2 response (Soos et al.2002). Treatment of NOD mice with IFNT either orally, intraperitoneally or subcutaneously delays or inhibits development of diabetes (Sobel et al. 2008). During pregnancy and in response to IFNT, MHC class I and $\beta 2$ microglobulin gene expression is silenced in uterine epithelia, but stimulated by IFNT in uterine stroma and glandular epithelium as a component of the mechanism(s) to prevent immune rejection of the conceptus allograft (Choi et al. 2003). These results indicate that IFNT affects the relative abundance of Th1 and Th2 cytokines produced by immune cells to favour a Th2 anti-inflammatory phenotype of tolerance expected to abrogate the progression of inflammatory diseases in humans and animals. IFNT inhibits human immunodeficiency virus (HIV) replication in vitro more effectively than human IFNA, particularly in human macrophages wherein it decreased intracellular HIV RNA and inhibited reverse transcription of viral RNA into proviral DNA (see Maneglier et al. 2008). Interferon tau increased synthesis of cellular antiviral factors including $2^{\prime}, 5^{\prime}$ oligoadenylate synthetase 1 , ribonuclease $L$ and myxovirus resistance 1 , mouse, homolog of proteins, as well as the anti-inflammatory cytokines interleukin 10 and interleukin 6 .

\section{Interferon tau and obesity}

Recognizing the link between inflammation, obesity and the anti-inflammatory properties of IFNT, studies were initiated to determine the effects of oral IFNT on time of onset of Type 2 diabetes (T2D), oxidation of glucose and fatty acids in insulin-sensitive tissues, energy expenditure, body mass and tissue weights in Zucker diabetic fatty (ZDF) rats, an animal model of T2D and obesity (see Tekwe et al. 2013). Oral administration of IFNT (8 $\mu \mathrm{g} /$ $\mathrm{kg}$ body weight/day) reduced oxidative stress, increased oxidation of energy substrates to $\mathrm{CO}_{2}$ in insulin-sensitive tissues, decreased white adipose tissue by $40 \%$, increased brown adipose tissue by $46 \%$, increased whole-body energy expenditure and ameliorated oxidative stress in insulin-sensitive tissues (i.e., decreased ratios of oxidized to reduced glutathione), and increased concentrations of the antioxidant tetrahydrobiopterin. Collectively, metabolic profiles were improved (Tekwe et al. 2013). Because IFNT stimulates oxidation of energy substrates and reduces obesity in ZDF rats, IFNT has important implications for treating obesity-related diseases.

Using a diet-induced obesity mouse model treated orally with IFNT in water $(8 \mu \mathrm{g} / \mathrm{kg} /$ day), insulin sensitivity in obese mice was enhanced. This was due to a significant decrease in secretion of proinflammatory cytokines and increases in anti-inflammatory macrophages (M2) and T-reg cells in white adipose tissue (Ying et al. 2014, 2016). Thus, IFNT can significantly mitigate obesity-associated systemic insulin resistance and tissue inflammation by controlling macrophage polarization and the population of anti-inflammatory T-reg cells.

\section{Summary}

The discovery of IFNT as the pregnancy recognition signal in ruminants and understanding of its mechanism of action have been established over the past few decades. This knowledge had led to translational research to explore its use for pregnancy diagnosis in ruminants by measuring it directly in maternal blood or assessing increases in the expression of interferonstimulated genes by immune cells in maternal blood. Further, the anti-inflammatory roles of IFNT in treatment of autoimmune diseases such as obesity, diabetes, multiple sclerosis, psoriasis and others remain to be explored through clinical trials to evaluate the potential therapeutic roles of the novel IFNT in treatment of human and animal conditions.

\section{Declaration of interest}

The authors declare that there is no conflict of interest that could be perceived as prejudicing the impartiality of this review..

\section{Funding}

This work was supported by funding from the United States Department of Agriculture (12-14-100-9962, 1972-1974; 61615-162, 1976-1980; 91-37203-6548, 1991-1992; 9202755, 1992-1994; 91-37203-6548, 1995-1998; 98-01983, 19982000; 2009-01722, 2009-2012; the National Institutes of Health (HD10436, 1980-1983; HD10436, 1983-1990; HD26006, 1989-1994; HD32534, 1996-2008; and the U.S.A.Israel Binational Agricultural Research and Development Fund (OEP 9604563, 1996-1999).

\section{Acknowledgements}

The authors gratefully acknowledge the contributions of graduate students, postdoctoral fellows and faculty member at both the University of Florida and Texas A\&M University who contributed to the research on pregnancy recognition signaling 
in pigs and ruminants. They have not cited each paper relevant to the history of IFNT, but additional papers can be obtained by querying PubMed. Between 1970 and 1985, the order in which authors were listed was the order of contribution to the work. After 1985, the corresponding author is the last author listed. Trainees were first author on most papers published based on results of their research for their respective graduate degree.

\section{References}

Adams CE 1960 Prenatal mortality in the rabbit, Oryctolagus cunicululs. Journal of Reproduction and Fertility 1 36-44. (doi:10.1530/ jrf.0.0010036)

Antoniazzi AQ, Webb BT, Romero JJ, Ashley RL, Smirnova NP, Henkes LE, Bott RC, Oliveira JF, Niswender GD, Bazer FW et al. 2013 Endocrine delivery of interferon $\mathrm{t}$ protects the corpus luteum from prostaglandin F2a-induced luteolysis in ewes. Biology of Reproduction 88 1-12.

Ashworth CJ \& Bazer FW 1989a Changes in ovine conceptus and endometrial function following synchronous embryo transfer or administration of progesterone. Biology of Reproduction 40 425-433. (doi:10.1095/biolreprod40.2.425)

Ashworth CJ \& Bazer FW 1989b Interrelationships of proteins secreted by the ovine conceptus and endometrium during the periattachment period. Animal Reproduction Science 20 117-130. (doi:10.1016/03784320(89)90069-9)

Basha SM, Bazer FW, Geisert RD \& Roberts RM 1980 Progesteroneinduced uterine secretions in pigs. Recovery from pseudopregnant and unilaterally pregnant gilts. Journal of Animal Science 50 113-123. (doi:10.2527/jas1980.501113x)

Bazer FW 1975 Uterine protein secretions: relationship to development of the conceptus. Journal of Animal Science 41 1376-1382. (doi:10.2527/ jas1975.4151376x)

Bazer FW \& Thatcher WW 1977 Theory of maternal recognition of pregnancy in swine based on estrogen controlled endocrine versus exocrine secretion of prostaglandin F2a by the uterine endometrium. Prostaglandins 14 401. (doi:10.1016/0090-6980(77)90295-7)

Bazer FW, Clawson AJ, Robinson OW, Vincent CK \& Ulberg LC 1968 Explanation for embryo death in gilts fed a high energy intake. Journal of Animal Science 27 1021-1026. (doi:10.2527/jas1968.2741021x)

Bazer FW, Clawson AJ, Robinson OW \& Ulberg LC 1969 Uterine capacity in gilts. Journal of Reproduction and Fertility 18 121-124. (doi:10.1530/ jrf.0.0180121)

Bazer FW, Geisert RD, Thatcher WW \& Roberts RM 1982 The establishment and maintenance of pregnancy. In Control of Reproduction in the Pig, pp 227-252. Eds DIA Cole \& GR Foxcroft. London: Butterworth Co.

Bazer FW, Spencer TE \& Johnson GA 2009 Interferons and uterine receptivity. Seminars in Reproductive Medicine 27 90-102. (doi:10.1055/ s-0028-1108013)

Bazer FW, Wu G, Johnson GA \& Wang X 2014 Environmental factors affecting pregnancy: endocrine disrupters, nutrients and metabolic pathways. Molecular and Cellular Endocrinology 398 53-68. (doi:10.1016/j.mce.2014.09.007)

Bazer FW, Ying W, Wang X, Dunlap KA, Zhou B, Johnson GA \& Wu G 2015a The many faces of interferon tau. Amino Acids 47 449-460. (doi:10.1007/s00726-014-1905-x)

Bazer FW, Johnson GA \& Wu G 2015b Amino acids and conceptus development during the peri-implantation period of pregnancy. Advances in Experimental Medicine and Biology 843 23-52. (doi:10.1007/978-14939-2480-6_2)

Bott RC, Ashley RL, Henkes LE, Antoniazzi AQ, Bruemmer JE, Niswender GD, Bazer FW, Spencer TE, Smirnova NP, Anthony RV et al. 2010 Uterine vein infusion of interferon $t$ (IFNT) extends luteal life span in ewes. Biology of Reproduction 82 725-735. (doi:10.1095/ biolreprod.109.079467)

Boyd H 1965 Embryonic death in cattle, sheep and pigs. Veterinary Bulletin 35 251-259.
Charpigny G, Reinaud P, Tamby JP, Créminon C, Martal J, Maclouf J \& Guillomot M 1997 Expression of cyclooxygenase-1 and -2 in ovine endometrium during the estrous cycle and early pregnancy. Endocrinology 138 2163-2171. (doi:10.1210/endo.138.5.5148)

Chaouat G, Meliani AA, Martal J, Raghupathy R, Elliot J, Mosmann T \& Wegmann TC 1995 IL-10 prevents naturally occuring fetal loss in the CBA X DBA/2 mating combination, and local defect in IL-10 production in this abortion-prone combination is corrected by in vivo injection of IFN- $\tau$. Journal of Immunology 154 4261-4268.

Chaouat G, Ledée-Bataillea N, Dubancheta S, Zourbasa S, Sandra O \& Martal J 2004 Th1/Th2 paradigm in pregnancy:paradigm lost? International Archives of Allergy and Immunology 134 93-119. (doi:10.1159/000074300)

Choi Y, Johnson GA, Burghardt RC, Berghman LR, Joyce MM, Taylor KM, Stewart MD, Bazer FW \& Spencer TE 2001 Interferon regulatory factor two restricts expression of interferon-stimulated genes to the endometrial stroma and glandular epithelium of the ovine uterus. Biology of Reproduction 65 1038-1049. (doi:10.1095/biolreprod65.4.1038)

Choi Y, Johnson GA, Spencer TE \& Bazer FW 2003 Pregnancy and interferon tau regulate major histocompatibility complex Class I and Beta-2microglobulin expression in the ovine uterus. Biology of Reproduction 68 1703-1710. (doi:10.1095/biolreprod.102.012708)

Eley RM, Thatcher WW \& Bazer FW 1979 Hormonal and physical changes associated with bovine conceptus development. Journal of Reproduction and Fertility 55 181-190. (doi:10.1530/jrf.0.0550181)

Ellinwood WE, Nett TM \& Niswender GD 1979 Maintenance of the corpus luteum of early pregnancy in the ewe. I. Luteotropic properties of embryonic homogenates. Biology of Reproduction 21 281-288. (doi:10.1095/biolreprod21.2.281)

Farin CE, Imakawa K, Hansen TR, McDonnell JJ, Murphy CN, Farin PW \& Roberts RM 1990 Expression of trophoblastic interferon genes in sheep and cattle. Biology of Reproduction 43 210-218. (doi:10.1095/ biolreprod43.2.210)

Fincher KB, Bazer FW, Hansen PJ, Thatcher WW \& Roberts RM 1986 Proteins secreted by the sheep conceptus suppress induction of uterine prostaglandin F2a release by estradiol and oxytocin. Journal of Reproduction and Fertility 76 425-433. (doi:10.1530/jrf.0.0760425)

Fischer HE, Bazer FW \& Fields MJ 1985 Steroid metabolism by endometrial and conceptus tissues during early pregnancy and pseudopregnancy in gilts. Journal of Reproduction and Fertility 75 69-78. (doi:10.1530/ jrf.0.0750069)

Fleming JGW, Bazer FW, Johnson GA, Choi YS \& Spencer TE 2001 Cloning of the ovine estrogen receptor alpha gene and regulation by interferon tau. Endocrinology 142 2879-2887. (doi:10.1210/endo.142.7.8245)

Fleming JGW, Spencer TE, Safe SH \& Bazer FW 2006 The ovine uterine oxytocin receptor gene: regulation of expression by estradiol and role of interferon tau signaling for establishment of pregnancy in ruminants. Endocrinology 147 899-911. (doi:10.1210/en.2005-1120)

Flint APF, Burton RD, Gadsby JE, Saunders PTK \& Heap RB 1979 Blastocyst oestrogen synthesis and the maternal recognition of pregnancy. In Maternal Recognition of Pregnancy, pp 209-238. Ed RB Heap. Amsterdam: Excerpta Medica.

Fowler RE \& Edwards RG 1957 Induction of superovulation and pregnancy in mature mice by gonadotrophins. Journal of Endocrinology $\mathbf{1 5}$ 374-384. (doi:10.1677/joe.0.0150374)

Geisert RD, Renegar RH, Thatcher WW, Roberts RM \& Bazer FW 1982a Establishment of pregnancy in the pig. I. Interrelationships between preimplantation development of the pig blastocyst and uterine endometrial secretions. Biology of Reproduction 27 925-939. (doi:10.1095/biolreprod27.4.925)

Geisert RD, Brookbank JW, Roberts RM \& Bazer FW 1982b Establishment of pregnancy in the pig. II. Cellular remodelling of porcine blastocysts during elongation on day 12 of pregnancy. Biology of Reproduction 27 941-955. (doi:10.1095/biolreprod27.4.941)

Geisert RD, Thatcher WW, Roberts RM \& Bazer FW 1982c Establishment of pregnancy in the pig. III. Endometrial secretory response to estradiol valerate administered on day 11 of the estrous cycle. Biology of Reproduction 27 957-965. (doi:10.1095/biolreprod27.4.957)

Godkin JD, Bazer FW, Moffatt J, Sessions F \& Roberts RM 1982 Purification and properties of a major, low molecular weight protein released by the 
trophoblast of sheep blastocysts at Day 13-21. Journal of Reproduction and Fertility 65 141-150. (doi:10.1530/jrf.0.0650141)

Godkin JD, Bazer FW, Thatcher WW \& Roberts RM 1984 Proteins released by cultured day 15-16 conceptuses prolong luteal maintenance when introduced into the uterine lumen of cyclic ewes. Journal of Reproduction and Fertility 71 57-64. (doi:10.1530/jrf.0.0710057)

Gossett JW \& Sorenson AM 1959 A comparison of embryo survival in gilts slaughtered twenty-five versus forty days after breeding. Journal of Animal Science 1848.

Guillomot M, Michel C, Gaye P, Charlier N, Trojan J \& Martal J 1990 Cellular localization of an embryonic interferon, ovine trophoblastin and its mRNA in sheep embryos during early pregnancy. Biology of the Cell 68 205-211. (doi:10.1016/0248-4900(90)90309-Q)

Hafez ESE 1964 Effects of over-crowding in utero on implantation and fetal development in the rabbit. Journal of Experimental Zoology 156 269-287. (doi:10.1002/jez.1401560304)

Hansen PJ, Anthony RV, Bazer FW, Baumbach GA \& Roberts RM 1985 In vitro synthesis and secretion of ovine trophoblast protein-1 during the period of maternal recognition of pregnancy. Endocrinology 117 1424-1430. (doi:10.1210/endo-117-4-1424)

Helmer SD, Hansen PI, Anthony RV, Thatcher WW, Bazer FW \& Roberts RM 1987 Identification of bovine trophoblast protein-1, a secretory protein immumologically related to ovine trophoblast protein-1. Journal of Reproduction and Fertility 79 83-91. (doi:10.1530/jrf.0.0790083)

Helmer SD, Hansen PJ, Thatcher WW, Johnson JW \& Bazer FW 1989 Intrauterine infusion of highly enriched bovine trophoblast protein-1 complex exerts an antiluteolytic effect to extend corpus luteumm lifespan in cyclic cattle. Journal of Reproduction and Fertility 87 89-101. (doi:10.1530/jrf.0.0870089)

Imakawa K, Anthony RV, Kazemi M, Marotti KR, Polites HG \& Roberts RM 1987 Interferon-like sequences of ovine trophoblast protein secreted by embryonic trophectoderm. Nature 330 377-379. (doi:10.1038/330377a0)

Jarpe MA, Pontzer CH, Ott TL, Bazer FW \& Johnson HM 1994 Predicted structural motif of interferon tau. Protein Engineering 7 863-867. (doi:10.1093/protein/7.7.863)

Knickerbocker J, Thatcher WW, Bazer FW, Drost M, Barron DH, Fincher KB \& Roberts RM 1986 Proteins secreted by day 16-18 bovine conceptuses extend corpus luteum function in cattle. Journal of Reproduction and Fertility 77 381-391. (doi:10.1530/jrf.0.0770381)

Kraeling RR, Rampacek GB \& Ball GD 1975 Estradiol inhibition of PGF2 $\alpha$ luteolysis in the pig. Journal of Animal Science $\mathbf{4 1} 363$.

Krishnan RS \& Daniel JC 1967 Blastokinin: inducer and regulator of blastocyst development in the uterus. Science 158 490-492. (doi:10.1126/science.158.3800.490)

Lewis GS, Basha SMM, Bazer FW, Roberts RM \& Thatcher WW 1979 Proteins originating from bovine and porcine blastocysts. Proceedings of the American Society of Animal Science 313

Maneglier B, Rogez-Kreuz C, Dereuddre-Bosquet N, Martal J, Devillier P, Dormont D \& Clayette P 2008 Anti-HIV effects of IFN-tau in human macrophages: role of cellular antiviral factors and interleukin-6. Pathology and Biology 56 492-503. (doi:10.1016/j.patbio.2008.06.002)

Martal J, Lacroix MC, Loudes C, Saunier M \& Winterberger-Torres S 1979 Trophoblastin, an antiluteolytic protein present in early pregnancy in sheep. Journal of Reproduction and Fertility 56 63-73. (doi:10.1530/ jrf.0.0560063)

McLaren A \& Michie D 1959 Studies on the transfer of fertilized eggs to uterine foster mothers. II. The effect of transferring large numbers of eggs. Journal of Experimental Biology 36 40-49.

Meyer MD, Drost M, Ott TL, Bazer FW, Badinga L, Li J, Roberts RM, Hansen PJ \& Thatcher WW 1995 Recombinant bovine and ovine interferon tau extend corpus luteum lifespan and reduce uterine secretion of prostaglandin $F_{2 \alpha}$ in cattle. Journal of Dairy Science 78 1921-1931. (doi:10.3168/jds.S0022-0302(95)76817-5)

Mirando MA, Ott TL, Harney JP \& Bazer FW 1990 Ovine trophoblast protein-one inhibits development of endometrial responsiveness to oxytocin in ewes. Biology of Reproduction 43 1070-1078. (doi:10.1095/ biolreprod43.6.1070)

Moor RM 1968 Effect of embryo on corpus luteum function. Journal of Animal Science 27 97-116.
Moor RM \& Rowson LEA 1966a Local maintenance of the corpus luteum in sheep with embryos transferred to various isolated portions of the uterus. Journal of Reproduction and Fertility 12 539-550. (doi:10.1530/ jrf.0.0120539)

Moor RM \& Rowson LEA 1966 b The corpus luteum of the sheep: effect of the removal of embryos on luteal function. Journal of Endocrinology 34 497-502. (doi:10.1677/joe.0.0340497)

Moor RM, Rowson LE, Hay MF \& Caldwell BV 1969 The corpus luteum of the sheep: effect of the conceptus on luteal function at several stages during pregnancy. Journal of Endocrinology 43 301-307.

Newton GR, Ott TL, Woldesenbet S, Shelton AH \& Bazer FW 1996 Biochemical and immunological properties of related small ruminant trophoblast interferons. Theriogenology 46 703-716. (doi:10.1016/0093691X(96)00222-1)

Noel S, Herman A, Johnson GA, Gray CA, Stewart MD, Bazer FW, Gertler A \& Spencer TE 2003 Ovine placental lactogen specifically binds to endometrial glands of the ovine uterus. Biology of Reproduction $\mathbf{6 8}$ 772-780. (doi:10.1095/biolreprod.102.009183)

Oliveira JF, Henkes LE, Ashley RL, Purcell SH, Smirnova NP, Veeramachaneni DN, Anthony RV \& Hansen TR 2008 Expression of interferon (IFN)stimulated genes in extrauterine tissues during early pregnancy in sheep is the consequence of endocrine IFN-Tau release from the uterine vein. Endocrinology 149 1252-1259. (doi:10.1210/en.2007-0863)

Ott TL, Heeke GV, Johnson HM \& Bazer FW 1991 Cloning and expression in S. cerevisiae of a synthetic gene for the pregnancy recognition hormone ovine trophoblast protein-1: purification and antiviral activity. Journal of Interferon Research 11 357-364. (doi:10.1089/jir.1991.11.357)

Perry JS, Heap RB \& Amoroso EC 1973 Steroid hormone production by pig blastocysts. Nature 245 45-47. (doi:10.1038/245045a0)

Platanias LC 2005 Mechanisms of type-I- and type-II-interferon-mediated signalling. Nature Reviews in Immunology 5 375-386. (doi:10.1038/ nri1604)

Pontzer CH, Torres BA, Vallet JL, Bazer FW \& Johnson HM 1988 Antiviral activity of the pregnancy recognition hormone ovine trophoblast protein-1. Biochemica Biophysica Research Communications 152 801-807. (doi:10.1016/S0006-291X(88)80109-8)

Pontzer CH, Ott TL, Bazer FW \& Johnson HM 1990 Localization of the antiviral site on the pregnancy recognition hormone, ovine trophoblast protein-one. PNAS 87 5945-5949. (doi:10.1073/pnas.87.15.5945)

Pontzer CH, Bazer FW \& Johnson HM 1991 Antiproliferative activity of a pregnancy recognition hormone, ovine trophoblast protein-1. Cancer Research 51 19-26.

Pontzer CH, Ott TL, Bazer FW \& Johnson HM 1994 Structure/function studies with interferon tau: evidence for multiple active sites. Journal of Interferon Research 14 133-141. (doi:10.1089/jir.1994.14.133)

Roberts RM 1991 A role for interferons in early pregnancy. Bioessays 13 121-126. (doi:10.1002/bies.950130305)

Roberts RM 1993 Interferon tau. Nature 362 583. (doi:10.1038/362583c0)

Robinson RS, Mann GE, Lamming GE \& Wathes DC 1999 The effect of pregnancy on the expression of uterine oxytocin, oestrogen and progesterone receptors during early pregnancy in the cow. Journal of Endocrinology 160 21-33. (doi:10.1677/joe.0.1600021)

Rowson LEA \& Moor RM 1967 The Influence of embryonic tissue homogenate infused into the uterus, on life-span of the corpus luteum in the sheep. Journal of Reproduction and Fertility 13 511-516. (doi:10.1530/jrf.0.0130511)

Schramm W, Bovaird L, Glew ME, Schramm G \& McCracken JA 1983 Corpus luteum regression induced by ultra-low pulses of prostaglandin F2 alpha. Prostaglandins 26 347-364. (doi:10.1016/00906980(83)90171-5)

Shirasuna K, Matsumoto H, Matsuyama S, Kimura K, Bollwein H \& Miyamoto 2015 Possible role of interferon tau on the bovine corpus luteum and neutrophils during the early pregnancy vein. Reproduction 150 217-225. (doi:10.1530/REP-15-0085)

Short RV 1979 When a conception fails to become a pregnancy. In Maternal Recognition of Pregnancy, pp 377-394. Ed RB Heap. Amerstadam: Excerpta Medica.

Simmons RM, Satterfield MC, Welsh TH Jr, Bazer FW \& Spencer TE 2010 HSD11B1, HSD11B2, PTGS2, and NR3C1 expression in the peri-implantation ovine uterus: effects of pregnancy, progesterone, 
and interferon tau. Biology of Reproduction 82 35-43. (doi:10.1095/ biolreprod.109.079608)

Soos JM, Stuve O, Youssef S, Bravo M, Johnson HM, Weiner HL \& Zamvil SS 2002 Cutting edge: oral type I IFN- $\tau$ promotes a Th2 bias and enhances suppression of autoimmune encephalomyelitis by oral glatiramer acetate. Journal of Immunology 169 2231-2235. (doi:10.4049/jimmunol.169.5.2231)

Sobel DO, Ahvazi B, Amjad F, Mitnaul L \& Pontzer C 2008 Interferon-tau inhibits the development of diabetes in NOD mice. Autoimmunity 41 543-53. (doi:10.1080/08916930802194195)

Spencer TE \& Bazer FW 1995 Temporal and spatial alterations in uterine estrogen receptor and progesterone receptor gene expression during the estrous cycle and early pregnancy in the ewe. Biology of Reproduction 53 1527-1545. (doi:10.1095/biolreprod53.6.1527)

Spencer TE \& Bazer FW 1996 Ovine interferon tau suppresses transcription of the estrogen receptor and oxytocin receptor genes in the ovine endometrium. Endocrinology 137 1144-1147. (doi:10.1210/ endo.137.3.8603586)

Spencer TE, Mirando MA, Ogle TF \& Bazer FW 1995a Ovine interferon- $\tau$ inhibits estrogen receptor up-regulation and estrogen-induced luteolysis in cyclic ewes. Endocrinology 136 4932-4944. (doi:10.1210/ endo.136.11.7588227)

Spencer TE, Becker WC, George P, Mirando MA, Ogle TF \& Bazer FW $1995 b$ Ovine Interferon- $\tau$ regulates expression of endometrial receptors for estrogen and oxytocin, but not progesterone. Biology of Reproduction 53 732-745. (doi:10.1095/biolreprod53.3.732)

Spencer TE, Ing NH, Ott TL, Mayes JS, Becker WS, Watson GH, Mirando MA \& Bazer FW 1995C Intrauterine injection of ovine interferon- $\tau$ $(\mathrm{IFN}-\tau)$ alters oestrogen and oxytocin receptor expression in the endometrium of cyclic ewes. Journal of Molecular Endocrinology $\mathbf{1 5}$ 203-220. (doi:10.1677/jme.0.0150203)

Spencer TE, Ott TL \& Bazer FW 1998 Expression of interferon regulatory factors one and two in the ovine endometrium: effects of pregnancy and ovine interferon tau. Biology of Reproduction 58 1154-1162. (doi:10.1095/biolreprod58.5.1154)

Spencer TE, Ott TL, Gertler A, Gootwine E \& Bazer FW 1999 Effects of recombinant ovine interferon tau, placental lactogen and growth hormone on the ovine uterus. Biology of Reproduction 61 1409-1418. (doi:10.1095/biolreprod61.6.1409)

Spencer TE, Johnson GA, Bazer FW \& Burghardt RC 2007 Fetal-maternal interactions during the establishment of pregnancy in ruminants. Reproduction 64 379-396 (doi:10.5661/rdr-vi-379)

Stewart HJ, McCann SH, Barker PJ, Lee KE, Lamming GE \& Flint AP 1987 Interferon sequence homology and receptor binding activity of ovine trophoblast antiluteolytic protein. Journal of Endocrinology $\mathbf{1 1 5}$ R13-R15. (doi:10.1677/joe.0.115R013)

Stewart DM, Johnson GA, Gray CA, Schuler LA, Burghardt RC, Joyce MM, Bazer FW \& Spencer TE 2000 Prolactin receptor and uterine milk protein expression in the ovine uterus during the estrous cycle and early pregnancy. Biology of Reproduction 62 1779-1789. (doi:10.1095/ biolreprod62.6.1779)

Stewart D, Johnson GA, Vyhlidal CA, Burghardt RC, Safe SH, Yu-Lee LY, Bazer FW \& Spencer TE 2001a Interferon tau activates multiple STAT proteins and has complex effects on interferon-responsive gene transcription in ovine endometrial epithelial cells. Endocrinology 142 1786-1794. (doi:10.1210/endo.142.5.8138)

Stewart DM, Johnson GA, Vyhlidal CA, Burghardt RC, Safe SH, Yu-Lee LY, Bazer FW \& Spencer TE 2001b Interferon-tau activates multiple signal transducer and activator of transcription proteins and has complex effects on interferon-responsive gene transcription in ovine endometrial epithelial cells. Endocrinology 142 98-107. (doi:10.1210/ endo.142.1.7891)

Tekwe CD, Lei J, Yao K, Rezaei R, Li X, Carroll RJ, Meininger CJ, Bazer FW \& Wu G 2013 Oral administration of interferon- $\tau$ enhances oxidation of energy substrates and reduces adiposity in Zucker diabetic fatty rats. Biofactors 39 552-563. (doi:10.1002/biof.1113)

Telgmann R1, Bathgate RA, Jaeger S, Tillmann G \& Ivell R 2003 Transcriptional regulation of the bovine oxytocin receptor gene. Biology of Reproduction 68 1015-1026. (doi:10.1095/biolreprod.102.008961)

Thatcher WW, Hansen PJ, Gross TS, Helmer SD, Plante C \& Bazer FW 1989 Antiluteolytic effects of bovine trophoblast protein-1. Journal of Reproduction and Fertility 37 91-99.

Tysseling KA, Thatcher WW, Bazer FW, Hansen PJ \& Mirando MA 1997 Mechanisms regulating prostaglandin $F_{2 \alpha}$ secretion from bovine endometrium. Journal of Dairy Science 81 382-389. (doi:10.3168/jds. S0022-0302(98)75588-2)

Vallet JL, Bazer FW, Fliss MFV \& Thatcher WW 1988 The effect of ovine conceptus secretory proteins and purified ovine trophoblast protein-one on interestrous interval and plasma concentrations of prostaglandins $\mathrm{F}_{2} \alpha, \mathrm{E}$ and 13,14-dihydro-15-keto-prostaglandin $\mathrm{F}_{2} \alpha$ in cyclic ewes. Journal of Reproduction and Fertility 84 493-504. (doi:10.1530/ jrf.0.0840493)

VanHeeke G, Ott TL, Strauss A, Ammaturo D \& Bazer FW 1996 High yield expression and secretion of the pregnancy recognition hormone ovine interferon- $\tau$ by Pichia pastoris. Journal of Interferon Research 16 119-126. (doi:10.1089/jir.1996.16.119)

Wilson ME, Lewis GS \& Bazer FW 1979 Proteins of ovine blastocyst origin. Proceedings of the Society for the Study of Reproduction 101A.

Yang L, Wang XL, Wan PC, Zhang LY, Wu Y, Tang DW \& Zeng SM 2010 Up-regulation of expression of interferon-stimulated gene 15 in the bovine corpus luteum during early pregnancy. Journal of Dairy Science 93 1000-1011. (doi:10.3168/jds.2009-2529)

Ying W, Kanameni S, Chang CA, Nair V, Safe S, Bazer FW \& Zhou B 2014 Interferon tau alleviates obesity-induced adipose tissue inflammation and insulin resistance by regulating macrophage polarization. PLOS ONE 9 e98835. (doi:10.1371/journal.pone.0098835)

Ying W, Tseng A, Chang CA, Wang H, Lin YL, Kanameni S, Brehm T, Morin A, Jones B, Criscitiello $\mathbf{M}$ et al. 2016 miR-150 regulates insulin sensitivity through controlling B cell functions. Scientific Reports 6 20176. (doi:10.1038/srep20176)

Ziecik AJ, Waclawik A, Kaczmarek MM, Blitek A, Jalali BM \& Andronowska A 2011 Mechanisms for the establishment of pregnancy in the pig. Reproduction in Domestic Animals 46 (Supplement 3) 31-41. (doi:10.1111/j.1439-0531.2011.01843.x)

Received 1 May 2017

First decision 12 June 2017

Revised manuscript received 4 July 2017

Accepted 26 July 2017 